\title{
Psycholinguistic Aspects of Realisation of Acme Potential of Life Scripts of Ukrainian Writers-Emigrants
}

\section{Психолінгвістичні ресурси реалізації акмепотенціалу життєвих сценаріїв українських письменників- емігрантів}

Halyna Handzilevska

Dr. in Psychology,

Associate Professor

\section{Галина Гандзілевська}

доктор психологічних наук, доцент

E-mail: halyna.handzilevska@oa.edu.ua orcid.org/0000-0002-6137-8344

Uliana Nikitchuk

Ph.D. in Psychology,

Associate Professor
Уляна Нікітчук

кандидат психологічних наук, доцент

$$
\begin{aligned}
& \text { E-mail: uliana.nikitchuk@ oa.edu.ua } \\
& \text { orcid.org/0000-0002-9820-3791 }
\end{aligned}
$$

Eduard Balashov

Ph.D. in Psychology, Associate Professor

\section{Едуард Балашов}

кандидат психологічних наук, доцент

$$
\begin{aligned}
& \text { E-mail: eduard.balashov@ oa.edu.ua } \\
& \text { orcid.org/0000-0002-6486-0494 } \\
& \text { SCOPUS ID: 56705096900 }
\end{aligned}
$$

* This research was funded by the Ministry of Education and Science of Ukraine, RN 0117U000683, "Metaknowledge in the Conditions of Individual and Psychological, Social and Situational Determination».

** Дослідження виконане за фінансової підтримки Міністерства освіти і науки України, Реєстраційний номер 0117U000683, «Метазнання в умовах індивідуального і психологічного, соціального й ситуаційного визначення». 
Психолінгвістичні ресурси реалізації акмепотенцііалу життєвих...

\author{
National University \\ of Ostroh Academy \\ 2, Seminarska Str., \\ Ostroh, Rivne Region, \\ Ukraine, 35800
}

\author{
Національний університет \\ «Острозька академія» \\ вул. Семінарська, 2, \\ Острог, Рівненська обл., \\ Україна, 35800
}

Original manuscript received February 05, 2019

Revised manuscript accepted September 15, 2019

\begin{abstract}
Introduction. This article has been devoted to the research of the issue of realization of psycholinguistic resources of acme potential of the Ukrainian writers and scientists whose activities are connected with generation of texts, in another cultural environment. So as to study the peculiarities of this process, which is the aim of the article, the main focus has been put on the empirical research of the correlation between the sociocultural adaptation of Ukrainian emigrants and the indicators of acmeological and psycholinguistic resources and on revealing differences in the indicators of resources and adaptation of Ukrainian emigrants who deal with writing and scientific activities in comparison with emigrants who do not.
\end{abstract}

Materials \& Methods. The life sense orientation, psychological position, and the sociocultural adaptation have been identified as the main indicators of acme realization of emigrants. Accordingly, the diagnostic instruments of the study included the Life Sense Orientation Test by D. Leontev, which is an adapted version of Purpose-In-Life Test by J. Crumbaugh \& L. Maholick, the "Fullness of Life» methodology by J. Powell and the Questionnaire of a Personality Adaptation to New Socio-Cultural Environment by L. Yankovskiy.

Results. It has been confirmed that the desire to self-realization of the emigrants depends on interest and emotional fullness of life, self-imagination and acceptance of others. The statistically confirmed results of the research have confirmed the differences between the indicators of resources and adaptation of the Ukrainian emigrants conducting writing and scientific activities, compared to the emigrants not conducting such activities. It has been stressed out that the Ukrainian emigrants generating texts have more harmonious type of adaptation, and more often perceive the process of life as full of sense compared to those emigrants whose activities do not include narrativization. The received results testify the importance of development of acme technologies for the Ukrainian emigrants through a prism of psycholinguistics methodology.

Key words: psycholinguistic resources, life script, acme potential, narrativization, writers-emigrants. 


\section{Introduction}

The issue of peculiarities of communicative activity and speech adaptation through generating of texts by Ukrainian writers-emigrants in the context of deployment of their life script, the new cognitive-emotional formation of an individual identification reflected in behavioral strategies of the internal model of own I, is one of the applied issues of psycholinguistics. The topicality of its solution is enhanced by the active international academic and professional mobility of the modern Ukrainians, whose age range coincides with the acme period, which is the most productive for achieving peak personality development. Considering that the transformation of identity in the conditions of emigration is accompanied by the loss of resources, it is important to study the factors of the restoration process and multiplication of acme potential of emigrants' life scripts, which involves the accumulation of external and internal resources for adaptation of the individual in the society and their maximum self-realization. Special attention is needed for studying the psycholinguistic resources of the deployment of the reflection-based process of self-knowledge of Ukrainian writers-emigrants (writers and scientists), the motivating force of which is the choice of goals and ways their essence realization, self-determination and aspiration for selfpresentation in a new cultural environment, in particular by the means of speech activity (text generating). Understanding the constructive potential of the psycholinguistic resources of the life script acme realization of the writers-emigrants can direct scientists in the direction of acmeologization of the representatives of the external and internal emigration and providing them with e ective psychological and acmeological support in di cult life situations.

\section{Literature Review of Previous Researches}

The issues of acmeologization of personality, as a process aimed at achieving the peaks of personal, professional, social and spiritual selfimprovement (Molodychenko, 2010) in the other cultural environment, are mostly presented in Ukraine in psychological and pedagogical researches. At the same time, the role of psycholinguistics in this process should be emphasized. Thus, the issues of intercultural adaptation, in 
particular, speech adaptation (Zasiekina, 2011; Tarasiuk, 2013), speech competency and speech experience (Orap, 2014), factors of adaptation, particularly, psycholinguistic means of forming productive bilingualism (Shyriaieva, 2010), have taken an important place among the national scientific interests of the last decade. Despite the present interest of psycholinguistics in addressing the issues of adaptation, there is a lack of research on the role of psycholinguistic resources in this process. The study of this issue in the measurement of the acme potential of the life scripts of Ukrainian writers-emigrants also requires a new perspective.

Resources and barriers of a personality's life-creative activities have usually been studied in the context of irrational and rational cognitions, which represent a complex of basic beliefs about oneself and the significance of others in the surrounding world, which largely depends on the relationship of a child with the parents (Berne, 2016; Stewart \& Joines, 2012; Steiner, 2013; Bleses et al., 2018; Ellis et al., 2017; Humeniuk, 2011; Karpenko \& Karpenko, 2015). Therefore, the technologies of optimization of modeling practices and life path correction are in the field of scientific interest. Important in this context is the issue of understanding and interpreting life experiences for personal growth. For the transformation of life experience, scientists determined narrativization as an e ective means of representation of subjective picture of the world and life sense (Tytarenko, 2012; Chepeleva, 2012, 2013). At the same time, its role for successful acmeologization of Ukrainian writers-emigrants, particularly realization of psycholinguistic resources, remains unclear. Insu cient theoretical study and empirical research of the outlined topic certifies about its relevance and practical need in its study.

\section{Aims and Tasks}

We assume that acme potential of life scripts of the Ukrainian writers-emigrants and scientists-emigrants, the professional activity of which is related to the generation of the narratives, will contain the di erences in the indicators of psycholinguistic and acme resources compared to those, whose activities are not connected with these types of creative activity. Therefore, the aim of this article is to reveal the results of studies and researches of realization of psycholinguistic 
resources of acme potential of life scripts by the Ukrainian emigrants scientists and writers.

Accordingly, the tasks of the research were directed at empirical determination of (1) dependence of sociocultural adaptation of the Ukrainian emigrants on acmeological potential of their life scripts;

(2) di erences in the indicators of acme potential of their life script scenarios, its realization and psycholinguistic resources concerning narrativization.

\section{Research Methods}

The following diagnostic instruments were used for accomplishing the aim and tasks of the article (Table 1).

Table 1. Diagnostic Instruments for Evaluation of Main Indicators

\begin{tabular}{|c|c|c|}
\hline Indicator & Methodology & Aim \\
\hline $\begin{array}{l}\text { Realization of } \\
\text { acme potential } \\
\text { of life scripts of } \\
\text { emigrants }\end{array}$ & $\begin{array}{l}\text { Questionnaire of a } \text { Personality } \\
\text { Adaptation to New Socio-Cultural } \\
\text { Environment by } \\
\text { (Yankovskiy, 2004) }\end{array}$ & $\begin{array}{l}\text { Determination of the level } \\
\text { and type of the adaptation of } \\
\text { emigrants to the another cultural } \\
\text { environment, taking into account } \\
\text { the specifics of their past } \\
\text { experience }\end{array}$ \\
\hline $\begin{array}{l}\text { Acme potential } \\
\text { of life script of } \\
\text { emigrants }\end{array}$ & $\begin{array}{l}\text { Methodology of J. Powell «Fullness } \\
\text { of Life» (Powell, 1993) }\end{array}$ & $\begin{array}{l}\text { Psychological } \\
\text { personality }\end{array}$ \\
\hline $\begin{array}{l}\text { Realization of } \\
\text { psycholinguistic } \\
\text { resourceq }\end{array}$ & $\begin{array}{l}\text { Life Sense Orientation (LSO) Test } \\
\text { by D. Leontev, an adapted version of } \\
\text { Purpose-In-Life Test by J. Crumbaugh } \\
\text { \& L. Maholick (Leontev, 2000) }\end{array}$ & $\begin{array}{l}\text { Research of individual } \\
\text { experiencing of the } \\
\text { significance of life }\end{array}$ \\
\hline
\end{tabular}

\section{Results and Discussion}

Speech activity, also considered as a certain «system of guidance», is one of the main issues of psycholinguistics (Kalmykova, 2011).

The mechanism of reflection, mechanism of speech memory, and mechanism of prediction are usually referred to the main psycholinguistic mechanisms of speech activity (Diachuk, 2015a). Given that the thought is the object of speech activity, and the language is the means (Diachuk, 2015b), these mechanisms can be considered as 
psycholinguistic resources for the realization of the acme potential of the life scenarios of writers and scientists, whose activities are related to generation of texts (product of speech activity), with a crucial role played by a mechanism of comprehension (Diachuk, 2015b).

The conceptual characteristics of the term «resources» is determined by the structure and character of these life necessities (adaptation, overcoming di cult life situations, certain kinds of activities, selfrealization etc.), which are intended to be ensured by the resources (Perevozchikova, 2012). Along with the transactional analysis in which life script is understood as the unconscious life plan (Berne, 2016), we rely on other theories of modern psychotherapy, in which this phenomenon has been studied as a «scheme» (Young, 2003), «script», «frame» (Ungerer \& Schmidt, 1996), «life orientation» (Guidano, 1995), that is, as a result of creative transformation of the primary data (perceptual, mnemonic information) by a person into the stable patterns of cooperation with the world and one's own personal conceptual system.

We determine modeling of the future as the common task of the life script in these theories. Therefore, adaptation of the personality to these processes is the task of its resources. It is obvious that implementation of such tasks cannot be considered outside the system of the personality's life senses, which are constructed through the reflexive correlation between the process of life and its predicted result. It is worth noting that the cognitive schemes of the personality are perceived as values, and therefore their implementation has personal meaning. Thus, the intentional aspects of life scripts in subjective terms appear as convictions (beliefs, attitudes), and in objective terms as motives. Since the conscious reflection of the future in the motives happens on the basis of past experience, it is obvious that the senses are a mechanism of formation of the life script resources and simultaneously a central psycholinguistic resource of realization of the life script acme potential (accumulative system of external and internal resources for adaptation of a person to society and their maximum selfrealization). This thesis has been confirmed by the results of our previous research (Handzilevska, 2018). In this research the life sense orientations as the main indicators of formation of acmeological potential of life scripts have been determined. The psychological analysis of the repertoire of the life roles 
presented in metaphoric narratives of the modern Ukrainian writersemigrants has been used.

According to the concept of acmeological resources of M. Khvatova (Khvatova, 2012), acme resources are considered to be the form of adaptive capabilities of a person, ensure the stability of their interaction with the environment, accordance with the norms of a society, personal goals and attitudes towards themselves. They are described from the position of individual and social, invariance and variability. In this regard, we consider the life script, which is a stable and typical behavioral strategy of the internal model of one's own self, to be an invariant for reaching acme in di erent spheres of life activities. This includes presence of variational components unique for each person, that provide adaptation to the changes while preserving emotional comfort, which is considered to be an indicator of e ective social adaptation and psychological health of the immigrant (Blinova, 2013). It is obvious that sociocultural adaptation is an indicator of realization of acme potential of life scripts of the Ukrainian emigrants, when «realization» points out to the reality.

It is worthwhile to note that the term «existential (psychological) life position of a child» is distinguished in transactional analysis, in which scientists associate the child script decisions with the existential life positions, their basic life setting, representing a complex of basic convictions about oneself and the surrounding world, largely depending on the child's relationships with the parents (Berne, 2016; Stewart \& Joines, 2012; Steiner, 2013). Convictions and beliefs as the cognitive-a ective formation of the personality, in a minimized form include a certain system of more or less conscious knowledge of the person about their own capabilities and the world as a whole, encouraging them to act in accordance with their own value orientations. Regardless of whether the convictions are rational or not, at the time of their formation they represent the senses of a personality and ensure execution of the functions of adaptation, overcoming, creative adaptation and modeling of the future the functions of the resources (Humeniuk, 2011). Therefore, we have reasons to consider the complex of convictions and beliefs, which is a certain life (psychological) position of a personality, as a notional concept and main indicator of the life script acme resources. Based on the theories of A. Beck and A. Ellis (Beck \& Ellis, 2000), in which the concept of irrational cognitive formations is interpreted 
as those hindering adequate adaptation, it is possible to distinguish the notional and life scripts: favorable if the convictions are rational, and unfavorable if they are irrational. Existential life position, in frames of transactional analysis, correlates with the script decisions, behavior schemes of a child, and therefore their life scripts (Steiner, 2013).

The mentioned above proves the importance of correction of «trigger» script mechanisms - drivers (directives), inspired to a child by the parents, for formation of the resource life script. It is likely that narration, the transformation of life experience into narrative structures, has contributed to this process (Chepeleva, 2013). Indeed, by constructing one's own personal narrative (as a verbal part of the life script (Kostina, 2013), a person constructs in one's own notional environment a certain hierarchy of life senses which structure and organize their individual life experience, and also build up a meaningful basis for construction of life scenarios (Chepeleva, 2012).

Together with this, on the example of psychological and historical reconstruction of acme scripts of such writers-emigrants as Dmytro Nytczenko, Lesia Bohuslavets, Ulas Samchuk and Oksana Liaturynska and the content, intent- and narrative analysis of their works (Handzilevska, 2016), it was observed that the patriotically oriented life position appearing in their rational beliefs and convictions, which we determine as the resource of their life script, in the long term helped the writers in preserving their national identity and contributed to resisting the assimilation processes and helping the e ective acmeologization which is reaching the peaks (acme) of personal, professional, social and spiritual self-improvement in another cultural environment (Molodychenko, 2010).

This, in turn, has been reflected in the literary works of the writers. Thus, the result of the statistical calculation of lexical units in the work of Vasyl Samchuk «Youth of Vasil Sheremeta» demonstrates the presence in the consciousness of U. Samchuk of knowledge about the peculiarities of his people, the author's understanding of himself as a representative of his people, who is called upon to preserve his own culture.

The intent - and content analysis of the poem «Testament» of the Ukrainian writer-emigrant Dmytro Nytczenko, conducted for identification of the psychological conditions and factors of preservation of patriotism by the writer, has enabled to claim that through the 
categories «connection» and «time» the intentional category «I» transforms to the category «We», which in turn emphasizes the unity of the author with the Ukrainian people. The quantitative indicator of the meaning sense units of the most expressed categories «close», «unity», «ability» $-\mathrm{G}=8$; verbal fullness of the selected categories according to the total amount of words (315 words) is: category «connection» $(3,8 \%)$, category «self-identification» $(3,49 \%)$, category «time» $(3,17 \%)$. In this poem of D. Nytczenko we have also determined the basic verbs, expressed in the call by such units as «love», «preserve», «glorify», which we interpret as an incentive to take direct action to defend the homeland at the proper time, which includes presentation and glorification of the own country abroad without allowing a shame in its address. Using the principles of narrative psychology, we see in this author's narrative an e ective need for the writer to serve his nation. Thus, the poetic testament of the author testifies both to the high level of patriotic consciousness and reflection of the writer, as well as to the sustainability of the public life position, which ensured the realization of strategic goal of the writer's life script.

In this research we focus on the role of psycholinguistic resources in the process of realization of life script acme potential of Ukrainian writersemigrants. A general empirical sample consisted of 64 respondents, representatives of overseas Ukrainians from Australia, USA, Canada, Great Britain, Bulgaria, Spain, Italy, Germany, France, Switzerland, Poland and China, and included the emigrants who are involved in literary and scientific activities (18 writers and 14 scientists, 32 persons not involved in either scientific or literature activities). In forming the empirical sample we took into account that chronologically, the acme period can be roughly defined by age limits from 16 till 55-60 (Humeniuk, 2011), the life script can be considered as formed before 20 years old (Berne, 2016), the age period 25-45 years old is sensitive for self-realization (Buhler, 1971; Balashov et al., 2016; Balashov, 2013).

The direct correlation between the indicators of such adaptation type as «Adaptability» and the scales of life sense orientations - «Process of Life» and «Locus of control - I», has been determined as a result of the correlation analysis (Pearson correlation coe cient was applied) of the data of the researched according to the questionnaire of the personality adaptation, Life Sense Orientation Test (LSO), 
methodology «Fullness of life» (Table 2). This, in turn, has proved that the desire of the emigrants for self-realization is dependent on the interest and the emotional richness of life, the perception of oneself as a strong personality who has enough freedom of choice for building one's own life in accordance with one's own goals and understanding of its sense. Besides, the direct correlation between the indicators of the emigrants' adaptation type "Adaptability» and the inverse correlation between the types «Depression», «Nostalgia» and «Alienation» with the indicator of the subscale «Which are others», proves the importance of the positive acceptance of others for the process of acmeologization (Leontiev, 2000; Yankovskiy, 2004).

In addition, the direct correlation between the type of adaptation of emigrants "Adaptability», and the reverse correlation between the types «Depression», «Nostalgia» and «Alienation» with the indicator «Which are Others», indicates the importance of positive acceptance of others and adequate self-esteem and self-value for realization of the life scripts acme potential. Direct correlation between the adaptation scales «Conformity», «Interactivity» with the scale «Which am I» confirm it.

Table 2. Meaningful correlations between the indicators of the type of adaptation and psycholinguistic and acmeological resources of an immigrant

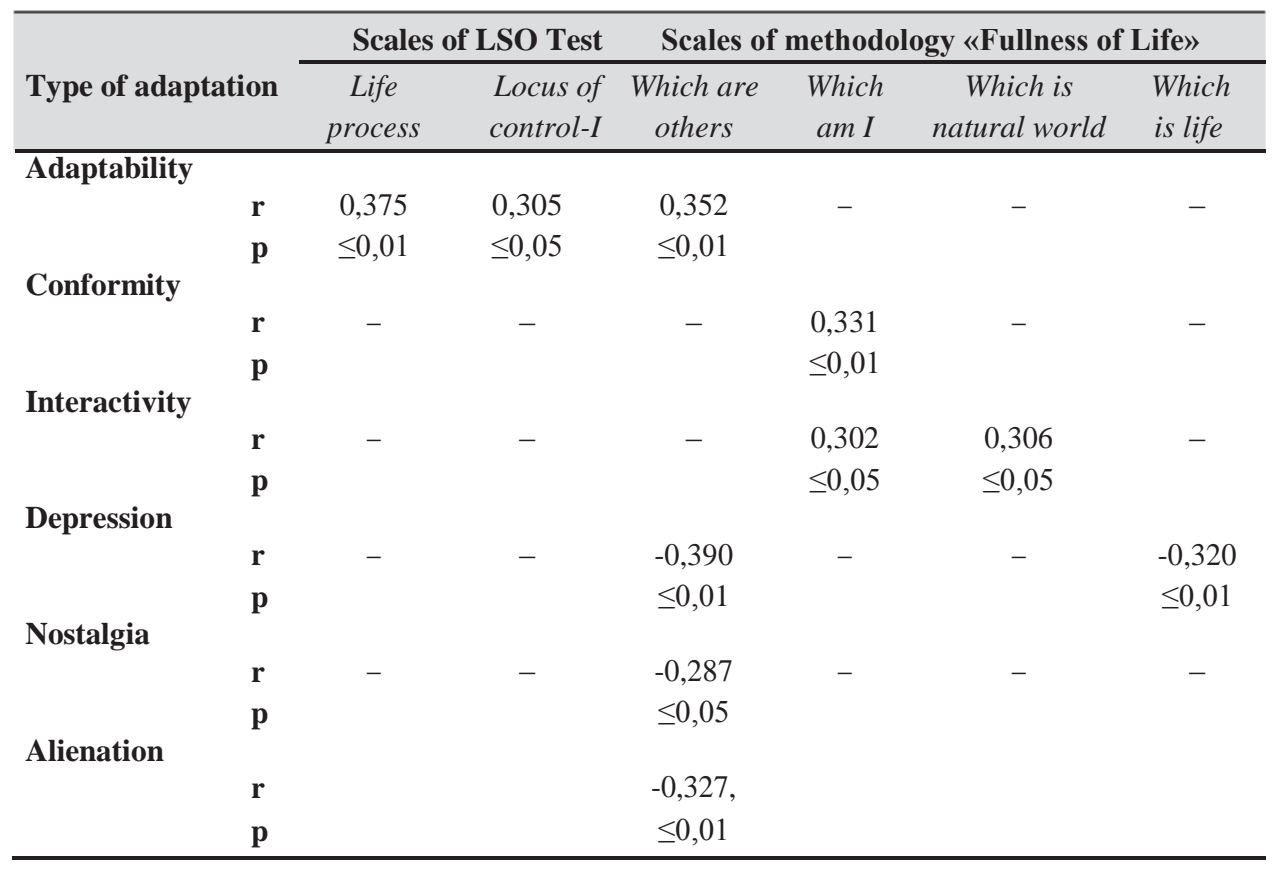


These results are confirmed by the inverse correlation between the scale «Depression» with the subscale «Which is life», and the direct correlation of the scale «Interactivity» with the subscale «Which is natural world». Thus, a positive attitude to life and knowledge of the surrounding world contribute to the active entering into the new environment and finding of new senses and values (Table 2).

It has been researched that the use of narration is statistically connected with socio-cultural adaptation, and namely the direct correlation with the type «Adaptability» $(, 303, \mathrm{p} \leq 0,05)$ and the inverse correlation with «Depression» $(-0,267, \mathrm{p} \leq 0,05)$; direct correlation with the subscale «Process of life» $(, 283, \mathrm{p} \leq 0,05)$, and the subscale «Which are others» $(, 279, p \leq 0,05)$. Therefore, it is possible to conclude that the Ukrainian emigrants created narratives, had more harmonious type of adaptation and more often accepted the life process as more interesting, emotionally intensive and full of sense compared to those ones whose activities did not include narrativization.

The use of Cohan's d criterion has allowed to determine the statistical significance of the di erences between the indicators of sociocultural adaptation of the writers-emigrants and not writers-emigrants, particularly such types as «Adaptability» $(\mathrm{d}=0,65)$ and «Depression» $(\mathrm{d}=0,56)$ (Figure 1).

\section{Types of Adaptation depending of the Use of Narrativization}

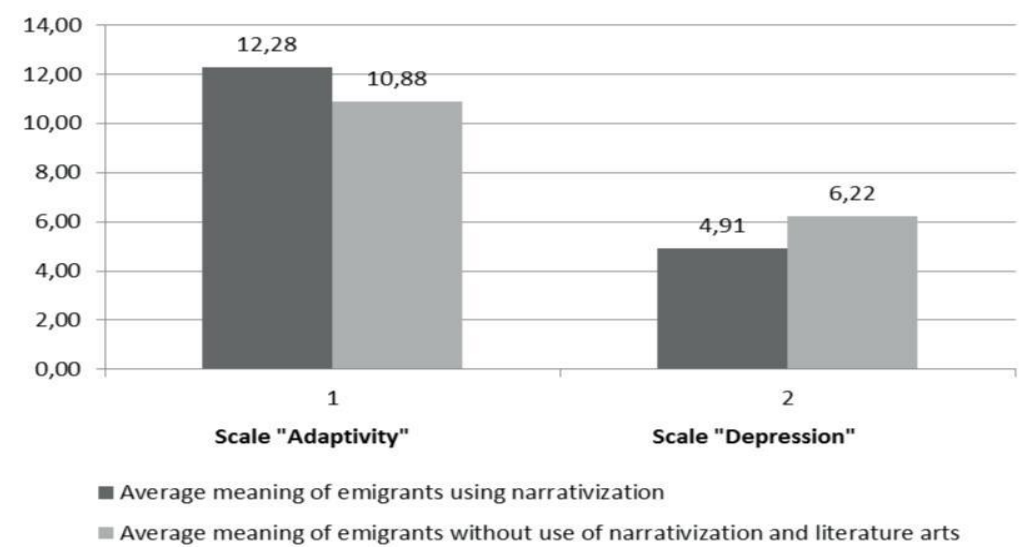

Figure 1. Types of Adaptation of Emigrant Depending of the Use of Narrativization 
Also, the statistical significance of the di erences between the indicators of life sense orientation of the writers-emigrants and not writers-emigrants of the subscale «Process of life» $(\mathrm{d}=0,60)$ (Figure 2$)$.

\section{Average Meanings according to Subscale "Process of Life" and LSO depending on the use of narrativization}

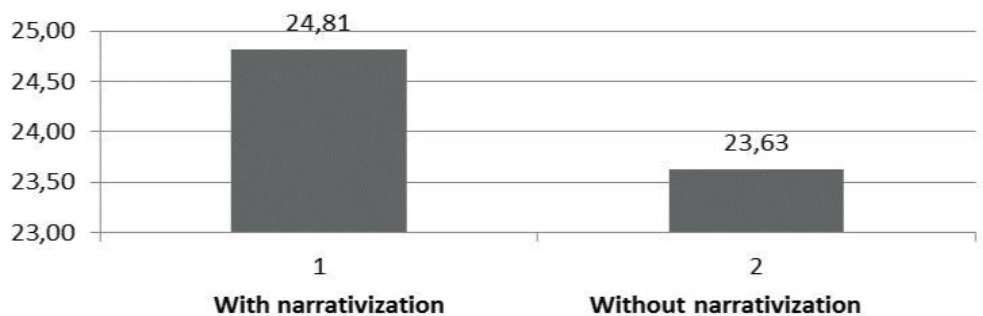

Figure 2. Average meanings of Subscales «Process of Life» and LSO Depending on the Use of Narrativization

The statistically significant di erences between such indicators of psychological position of the writers-emigrants and not writers-emigrants of the subscale «Which are others» $(\mathrm{d}=0,585)$ have been found out (Figure 3)

\section{Differences in averages in subscale "Which are Others"}

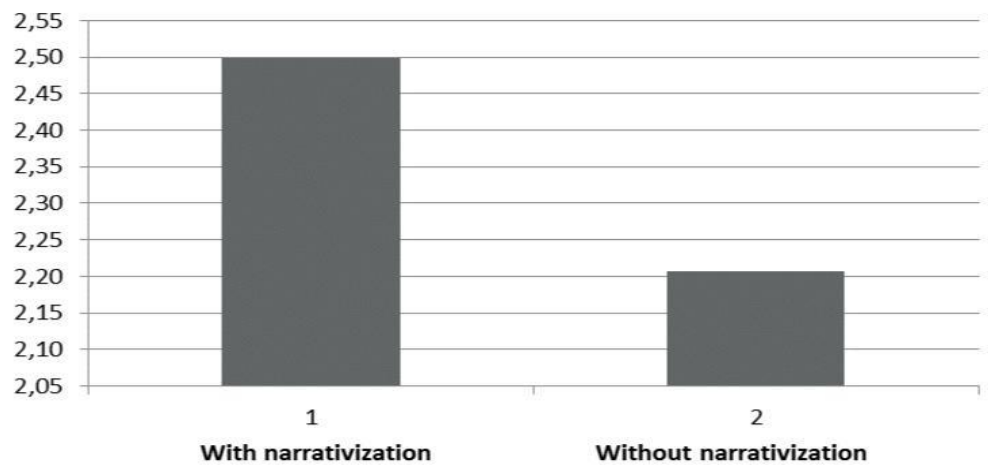

Figure 3. Differences in Average Meanings of Subscales «Which are others» of Methodology «Fullness of Life» 
These results suggest that the narration, the functions of which are realized by literary and scientific activities (Afanasiev \& Vasylenko, 2015), is one of the factors of di erences between the indicators of the acmeological potential of life scripts of Ukrainian emigrants, its

implementation and psychological resources. Therefore, generating of artistic and which provides scientific texts as a form of sense-making process, can be considered a constructive factor of acme realization of Ukrainian emigrants.

Constructive and destructive factors of creative potential selfrealization of a person in the process of acmeologization are primarily the subject of interest in psychological and acmeologic studies. It is necessary to note the works of N. Kuzmina (Kuzmina, 2015), who has associated the cause of the decrease productive results in the new conditions with the matrix of orientation (abilities, motives, responsibility, competence, skills or capability); U. Humeniuk (Humeniuk, 2011) who has empirically identified the connection between irrational beliefs, considered by the author in the context of the motive of avoidance, and meaning-generating processes which are the indicators of acmeologization; S. Maksimova (Maksimova, 2006) who has emphasized the dependence of the forms of creative activity of the person (nonadaptive and adaptive) from child script decisions-prohibitions and prescriptions (psychological barriers) etc.

In the context of studying the parental prohibitions it should be noted that the Danish psychologists (Bleses et al., 2018) have determined a correlation between the frequency of use of certain words (including directive ones) in relation to children and such variables as education of mother, child's gender, number and order of the birth of children in the family. For example, in the families with a few children, the word «to rush» was recorded significantly more often than in the families with one child. In In the fundamental complex longitude study (Ellis et al., 2017), the patterns of responses to stress have appeared to be adaptive in biological sense (since they ensure survival). Studying the role of early childhood experience in formation of the life history strategies as a part of the system of response to stress (Ellis et al., 2009), the scientists point out that the quality of parental «investments» in a child (emphasis on providing the resources and strict parental discipline, as opposed to warm and supportive parental behavior) is the source, from 
which the children receive information about the risks and opportunities of their surrounding environment. This thesis has overlapped with the results of our study.

In our previous researches (Pasichnyk et al., 2017), on a basis of correlative analysis, we determined a connection between the personal readiness for changing of internally displaced people, which is one of the adaptation factors, to script settings (early child decisions). The subscale «Confidence» turned out to be inversely related to scenario bans «Do not be successful», «Do not do» and «Do not be a child»; indicators of the subscale «Inventiveness» are lower when the bans «Do not grow up», «Do not be successful» and «Do not do» are clearly expressed; the subscale «Optimism» inversely correlates with the ban «Do not be successful»; the subscales «Courage» and «Tolerance» are inversely correlated with the script ban «Do not belong». According to the results of the mentioned research, the script bans inversely correlate with the scales of the questionnaire of Life-sense orientations. The persons lacking life goals (subscale «Life Goals») have clearly introjected bans «Do not show up» and «Do not be yourself». Persons with a low interest to their lives and emotional fullness of lives (subscale «Process of Life») are driven by the bans «Do not be yourself», «Do not be successful», «Do not create», and by the drivers «Strive» and «Hurry up». Satisfaction with their own selfrealization is lower when the bans «Do not be yourself» and «Do not be successful» are more clearly expressed. Considering the fact that senses are the criteria for reaching acme (Bodalev, 1998), we conceive the singled out bans to be the acme barriers. All this illustrates and specifies the above-mentioned thesis that unsuccessful life script based on irrational cognitions impedes e cient adaptation and acme realization.

The previous results of the study are validated at the sample of the Ukrainian emigrants - representatives of Ukrainians overseas from Poland, Germany, Czech Republic, Slovak Republic, Finland, Portugal, Belgium, Netherlands, France, Great Britain, USA, Austria, Canada, Norway, Italy, Denmark, Switzerland, Mozambique, the countries of Eastern Asia and others ( $\mathrm{n}=103)$ (Handzilevska, 2018).

The statistically confirmed correlation of scrip decisions of the emigrants with such types of socio-cultural adaptation «Adaptability», «Conformity», «Depression», «Nostalgia», «Alienation», has given us reasons to distinguish such irrational script decisions («Do not 
be a child», «Do not be successful», «Do not be first», «Do not be meaningful», «Do not be (not show up)», «Do not become closer», «Do not be yourself», «Do not be healthy», «Do not grow up», «Do not feel», «Do not belong») to be the psychological barriers for the emigrants' sociocultural adaptation and self-realization, which in turn broadens the limits of understanding the acme barriers and reasons for disadaptation to the new other socio-cultural environment. It has been determined that life script as an invariant of acmeologization of the emigrants in the conditions of their adaptation to a new socio-cultural environment requires some corrections of its variable components, in particular the destructive script settings. In this regard, there have been identified the constructive factors of the emigrants' acmeologization, which direct the searches of the ways to optimize this process.

\section{Conclusions}

The obtained in this research results help to solve the actual psychological and psycholinguistic issues that are in the sphere of interest of modern Ukrainian scientists, and namely, searching by a person for the e ective methods of the process of development of one's life cautiousness, optimizing social and psychological practices of modeling the life path, particularly understanding and interpretation of life experience of personal growth by the means of self-regulation (Balashov et al., 2018) and narrativization (Tytarenko, 2012).

Following U. Humeniuk (Humeniuk, 2010), we adhere to the idea of inexpediency of designing typology of acme-capable and acme-incapable personalities, and expediency of studying the constructive factors of the process of achieving the peak development instead, which in turn has directed our scientific and practical interest.

There has been found and confirmed a direct correlation between the indicators of such type of adaptation as «Adaptability», and the scale of life sense orientation «Process of Life» and «Locus of Control I»; direct correlation between the indicators of emigrants «Adaptability» and reverse correlation between «Depression», «Nostalgia» and «Alienation» with the indicator of scale «Which are Others»; direct correlation between the adaptation scales «Conformity», «Interactivity» with the scale «Which am I» confirm it. Thus, it has been confirmed 
that the desire to self-realization of the emigrants depends on interest and emotional fullness of life, self-imagination and positive acceptance of life.

The statistically significant di erences in the indicators of sociocultural adaptation, life sense orientations and fullness of life of the writers-emigrants compared to not writers have allowed determining narrativization, the function of which is executed by the literary and scientific activities, as a factor of di erences of the indicators of acme development potential of life scripts of the Ukrainian emigrants, its realization and psycholinguistic resources.

There have been distinguished significant di erences for the scale «Adaptability» of the adaptability questionnaire; found out significant di erences for the scale «Fullness of life» of the LSO questionnaire; determined significant di erences for the scale «Which are others» of the «Fullness of life» methodology. It has been stressed out that the Ukrainian emigrants creating narratives have more harmonious type of adaptation, and more often perceive the process of life as full of sense compared to those emigrants whose activities do not include narrativization. This, in turn, provides reasons to distinguish narrativization as the constructive factor in optimization of the process of realization of life script acme potential of the Ukrainian writers-emigrants. At the same time, consideration of psycholinguistic resources in the process of acmeologization may lead to a new perspective on the development of technologies of psychological support for the emigrants. We consider the prospect of further research in including psycholinguistic resources to the development of technologies of psychological and acmeological support of Ukrainian emigrants.

\section{References}

Afanasiev, O., \& Vasylenko, I. (2015). Funktsii naratyvu u naukovomu teksti. [Functions of Narrative in Scientific Text]. SWorld Journal. Access Mode: http:// www.sworld.com.ua/simpoz5/20.pdf.

Balashov, E. (2013). Teoretychni i empirychni osnovy modeli samorealizatsiji studentskoji molodi u mizhnarodnykh volonterskykh programakh [Theoretical and Empirical Foundations of a Model of Self-Realization of Academic Youth in International Volunteer Programs] (E-edition). Zhurnal Natsionalnoji Akademiji Prykordonnoji Sluzhby Ukrajiny - Journal of National Academy of Border Service of Ukraine, 3. Retrieved from: www.nbuv.gov.ua/e-journals/ Vnadps/2013_3/13bemmvp.pdf [in Ukrainian]. 
Balashov, E., Pasichnyk, I., \& Kalamazh, R. (2016). Intercultural Components of Student Self-Realization in International Volunteering Programmes. Annual of Social Work, 23(1), 123-139 https://doi.org/10.3935/ljsr.v23i1.73

Beck, A., \& Ellis, A. (2000). New Concept in Practice: On Therapy - A Dialogue with Aaron T. Beck and Albert Ellis (Washington DC, August 4-8, 2000). American Psychological Association. 108 th Convention. Washington DC. Retrieved from: www.fenichel.com/Beck-Ellis.shtml

Berne, E. (2016). Games People Play: The Psychology of Human Relationships. London: Penguin.

Bleses, D., Vach, W., \& Dale, P. (2018). Self-Reported Parental Vocabulary Input Frequency for Young Children. Journal of Child Language, 45(5), 1-18 https:// doi.org/10.1017/S0305000918000089

Blinova, O. (2013). Psihologichne zdorov'ja migrantiv: rezul'tati empirichnogo doslidzhennja [Psychological Health of Emigrants: Results of Empirical Research]. Osvita regionu - Education of Region, 2, 244-248.

Bodalev, A. (1998). Vershyna razvitija vzroslogo cheloveka: kharakteristiki i uslovija dostizhenija [Peak in Development of Adult: Characteristics and Conditions of Reaching]. Moscow: Flinta-Nauka [in Russian].

Buhler, C. (1971). Basic Theoretical Concepts of Humanistic Psychology. American Psychology, 26(4), 39-52 https://doi.org/10.1037/h0032049

Chepeleva, N. (2012). Samoproektuvannia osobystosti v dyskursyvnomu prostori [SelfProjection of Personality in Discursive Environment]. Naukovi studii z sotsialnoji $i$ politychnoji psykhologii - Scientific Studies in Social and Political Psychology, 31, 12-20 [In Ukrainian].

Chepeleva, N. (Ed.). (2013). Rozuminnia ta interpretatsija zhyttievogo dosvidu jak faktor personalnogo rozvytku [Understanding and Interpretation of Life Experience as Factor of Personal Development]. Kirovohrad: Imeks-LTD [in Ukrainian].

Diachuk, N. (2015a). Psycholinguistic Mechanisms of Speech Activity of an Interpreter [Psykholingvistychni mekhanizmy movlennievoji dijalnosti perekladacha]. Suchasni lingvistichni studiï HHI stolittja. Tezi dopovidej Vseukraïns'koï naukovopraktichnoï zaochnoï konferenciï - Modern Linguistic Studies of the XXI Century. Abstracts of Presentations of All-Ukrainian Scientific and Practical Distance Conference (pp. 26-29). Zhitomir.

Diachuk, N. (2015b). Realities of Speech Activity: Psycholinguistic Approach [Realiji movlennievoji dijalnosti: Psykholingvistychnyj pidkhid]. Naukovi zapiski Nacionalnogo universitetu «Ostrozka akademija»-Scientific Notes of the National University of Ostroh Academy, 58, 257-260.

Ellis, B., Oldehinkel, A., \& Nederhof, E. (2017). The Adaptive Calibration Model of Stress Responsivity: An Empirical Test in the Tracking Adolescents' Individual Lives Survey Study. Development and Psychopathology, 29(3), 1001-1021 https://doi.org/10.1017/S0954579416000985

Ellis, B.J., Figueredo, A.J., Brumbach, B.H., \& Schlomer, G.L. (2009). Fundamental Dimensions of Environmental Risk: The Impact of Harsh Versus Unpredictable Environments on the Evolution and Development of Life History Strategies. Human Nature, 20, 204-268 https://doi.org/10.1007/s12110-009-9063-7

Guidano, V.F. (1995). Constructivist psychotherapy: A theoretical framework. In R.A. Neimeyer \& M.J. Mahoney (Eds.), Constructivism in Psychotherapy 
(pp. 93-108). Washington, DC, US: American Psychological Association. http:// dx.doi.org/10.1037/10170-004

Handzilevska, G. (2018). Zhyttievi stsenariji Ukrajinskykh emigrantiv (prykhologichni $i$ akmeologichni resursy) [Life Scripts of Ukrainian Emigrants (Psychological and Acmeological Resources)]. Ostroh: National University of Ostroh Academy [in Ukrainian].

Humeniuk, U. (2010). Irratsionalni viruvannia liudyny jak kognityvni utvorennia [Irrational Beliefs of a Person as Cognitive Formations]. Naukovyj Biuleten Chernivetskogo natsionalnogo universytetu. Serija «Psykhologija i pedagogika»Scientific Bulletin of Chernivtsi National University: Collection of Scientific Papers. Series «Pedagogy and Psychology», 14, 120-131 [in Ukrainian].

Humeniuk, U. (2011). Osoblyvosti irratsionalnykh viruvan u akmeperiodi liudyny v zalezhnosti vid dominujuchoji psychologicznoji funktsiji i zagalnogo stanu svidomosti [Peculiarities of Irrational Beliefs of Acme Period of a Person Depending on Dominating Psychological Function and General Setting of Consciousness]. Extended Abstract of Candidate's Thesis. Khmelnytsky: KhNABG [In Ukrainian].

Kahler, T., \& Capers, H. (1974). The Miniscript. Transactional Analysis Journal, 4(1), $26-42$.

Kalmykova, L. (2011). Psykhologija rozvytku movlennievoji dijalnosti ditej doshkilnoho viku [Psychology of Development of Speech Activity of Preschool Age Children]. Doctor's Theses [in Ukrainian].

Karpenko, Z., \& Karpenko, Y. (2015). Subjektni mekhanizmy aksiogenezu osobystosti [Subjective Mechanisms of Axio Genesis of Pesonality]. Psihologichni perspektivi: teorija i praktika - Pedagogical Process: Theory and Practice, 3-4, 5-11 [in Ukrainian].

Khvatova, M. (2012). Kontseptsyja razvitija akmeologicheskikh resursov psikhologicheskogo zdorovja molodezhy [Concept of Development of Acmeologic Resources of Psychological Health of Youth]. Extended Abstract of Doctor's Thesis. Tambov: TSU [in Russian].

Kostina, T. (2013). Narrativnyj component zhyznennogo stsenarija lichnosti [Narrative Component of Life script of Personality]. Mezhdunarodnyj nauchnyj forum: Sotsiologija, psikhologiya, pedagogika, menedzhment - International Scientific Forum: Sociology, Psychology, Pedagogy, Management, 13, 163-169 [in Ukrainian].

Kuzmina, N. (2015). Fundamentalna akmeologija jak najbilsh vazhlyvyj resurs protsesu pidvyshchennia produktyvnosti osvity [Fundamental Acmeology as the Most Important Resource of Process of Increasing the Productivity of Education]. Problemy osvity - Problems of Education, 84, 14-19 [in Ukrainian].

Leontev, D. (2000). Test smyslozhyznennykh orientatsyj [Life Sense Orientation Test] (2nd ed.). Moscow: Smysl [in Russian].

Maksimova, S. (2006). Kreativnost: Sozidanije ili razruhenije [Creativity: Creation or Destruction]. Moscow: Akademicheskiy proekt [in Russian].

McMullen, R. (2001). Praktikum po kognitivnoj terapii [Practicum in Cognitive Therapy]. Saint-Petersburg: Rech [in Russian].

Molodychenko, T. (2010). Stratumericheskaja kontseptsija akmeologizatsyji lichnosti i sotsyalnaja stratifikatsija lichnosti $\mathrm{v}$ obshchestve [Stratumeric Concept of Acmeologization of Personality and Social Stratification of Society]. Biulleten Saratovskogo universiteta, Novyje serii. Serija «Filosofija. Psikhologija. 
Pedagogika» - Bulletin of Saratov University, New Series. Series «Philosophy. Psychology. Pedagogy», 1, 83-87 [in Russian].

Orap, M. (2014). Movlennieva kompetentsija ta movlennieva diajlnist u strukturi movlennievoho dosvidu osobystosti [Speech Competence and Speech Activity in a Structure of Speech Experience of Personality]. Visnik Harkivskogo nacionalnogo pedagogichnogo universitetu imeni G.S. Skovorodi. Psihologija - Bulletin of H. Skovoroda Kharkiv National Pedagogical University. Psychology, 48, 178-191 [in Ukrainian].

Pasichnyk, I., Handzilevska, H., \& Nikitchuk, U. (2017). Psychological immunity of Ukrainian migrants depending on childhood scenario sets. Psihologichni perspektivi: teorija i praktika - Psychological Prospects: Theory and Practice, 30, $145-156$.

Perevozchikova, O. (2012). Fenomenologichnyj analiz resursiv osobystosti Phenomenological Analysis of Personality's Resources. Retrieved from: http:// umo.edu.ua/images/content/nashi_vydanya/stud_almanah/41.pdf. [in Ukrainian].

Powell, J. (1992). Polnota chelovecheskoj zhizni [Fullness of Life]. Moscow: Community Orthodox University of A. Men [in Russian].

Shyriaieva, T. (2010). Kompleksnyj psykholingvistychnyj trening jak zasib formuvannia produktyvnoho bilingvizmu [Complex Psycholinguistic Training as a Means of Forming Productive Bilingualism]. Naukovi zapiski Nacionalnogo universitetu "Ostrozka akademija» - Scientific Notes of the National University of Ostroh Academy, 15, 249-254 [in Ukrainian].

Steiner, C. (2013). Stsenarii chelovecheskikh zhyzniej. Shkola Erika Berne [Scripts of People's Lives. School of Eric Berne]. St. Petersburg: Piter [in Russian].

Stewart, I., \& Joines, V. (2012). TA Today: A New Introduction to Transactional Analysis. Nottingham, UK: Lifespace Publishing.

Tarasiuk, I. (2013). Psykhologichni osoblyvosti movlennievoji adaptatsiji ditej migrantiv do inshomovnoho seredovyshcha [Psykhoogical Peculiarities of Speech Adaptation of Children of Migrants to other Languages Environment]. Candidate's thesis [in Ukrainian].

Tytarenko, T. (2012). (Ed.). Yak zbuduvaty vlasne majbutnie: zhyttievi zavdannia osobystosti [How to Build Own Future: Life Tasks of a Personality]. Natsionalna akademija pedagogichnykh nauk Ukrajiny, Instytut sotsialnoji $i$ praktychnoji psykhologiji - National Academy of Pedagogical Sciences of Ukraine, Institute of Social and Political Psychology. Kirovohrad; Imeks Ltd [in Ukrainian].

Ungerer, F., \& Schmid, H.J. (1996). An Introduction to Cognitive Linguistics. Harlow: Longman.

Yankovskiy, L. (2004). Adaptatsyja lichnosti k novoj sotsyokulturnoj srede [Adaptation of Personality to New Socio-Cultural Environment]. Psikhodiagnosticheskoje Znanije Professionalnoj Dejatelnosti - Psychodiagnostic Knowledge of Professional Activities (pp. 206-211). Saint-Petersburg: Rech [in Russian].

Young, J.E., Klosko, J.S., \& Weishaar, M. (2003). Schema Therapy: A Practitioner's Guide. NewYork: Guilford Publications.

Zasiekina, L. (2011). Movlennieva adaptatsija osobystosti jak predmet psykholingvistychnoho doslidzhennia [Speech Adaptation of Personality as a Subject of Psycholinguistic Research]. Psihologichni perspektivi: teorija $i$ praktika - Pedagogical Process: Theory and Practice, 17, 104-116 [in Ukrainian]. 


\section{АНОТАЦІЯ}

Вступ. Стаття присвячена дослідженню проблеми реалізації психолінгвістичних ресурсів акмеологічного потенціалу життєвих сценаріїв українських письменників та науковців (письменників) в інокультурному середовищі. Для вивчення особливостей цього процесу, що є метою статmі, увагу зосереджено на емпіричному вивченні кореляційного зв'язку соціокультурної адаптації українських мігрантів з показниками акмеологічних й психолінгвістичних ресурсів та дослідженні відмінностей у показниках ресурсів та адаптації українських емігрантів, які займаються письменницькою та науковою діяльністю у порівнянні з емігрантами, які нею не займаються.

Матеріали й методики дослідження. Основними показниками акме-реалізації емігрантів виділено смисложиттєві орієнтації, психологічну позицію, соціокультурну адаптацію. Діагностичний інструментарій відповідно включив тест смисложиттєвих орієнтацій (Д. Леонтьєва), що є адаптованою версією тесту «Ціль в житті» (Purpose-in-LifeTest, PIL) Джеймса Крамбо і Леонарда Махоліка, методику Дж. Пауелла «Повнота життя», опитувальник адаптації особистості до нового соціокультурного середовища (за Л. Янковським).

Результати. Корелячійний аналіз показав значимі помірні кореляції між:

(1) адаптивністю як типом адаптації та орієнтацією на процес життя й внутрішнім локусом контролю; (2) депресивністю, ностальгією, відчуженістю як типами адаптації та шкалою "Які інші» методики «Повнота життя»;

(3) конфрормністю, інтерактивністю як типами адаптації та шкалою "Який я» методики «Повнота життя». Таким чином з'ясновано, що прагнення до самореалізації емігрантів є залежним від інтересу та емоційної насиченості життя, уявлення про себе та сприйняття інших.

Статистично підтверджені результати дослідження свідчать й про відмінності у показниках ресурсів та адаптації українських емігрантів, які займаються письменницькою та науковою діяльністю у порівнянні з емігрантами, які нею не займаються.

Виявлено значимі відмінності для шкали "Адаптивність» та «Депресивність» опитувальника адаптаціі; прослідковано значимі відмінності для шкали «Процес життя» опитувальника смисложиттєвих орієнтацій; досліджено значимі відмінності й для шкали "Які інші» методики «Повнота життя». Наголошено, що українські мігранти, які генерують тексти, мають більш гармонійний тип адаптації, частіше сприймають процес життя як сповнений смислу, порівняно із тими емігрантами, чия діяльність не включає наративізації. Оттимані результати свідчать про вагомість розробки акме технологій для українських емігрантів крізь призму методології психолінгвістики.

Ключові слова: психолінгвістичні ресурси, життєвий сценарій, акме-потенціал, наративізація, письменники-емігранти. 
Psycholinguistic Aspects of Realisation of Acme Potential of Life...

Гандзилевская Галина, Никитчук Уляна, Балашов эдуард.
Психолингвистические ресурсы реализации акмепотенциала жизненных
сценариев украинских писателей-эмигрантов

\section{АННОТАЦИЯ}

Вступление. Статья посвящена исследованию проблемы реализации психолингвистических ресурсов акмеологического потенциала жизненных сценариев украинских писателей и ученых (писателей) в инокультурной среде. Для изучения особенностей этого прочесса, что является челью статьи, внимание сосредоточено на эмпирическом изучении корреляционной связи социокультурной адаптации украинских мигрантов с показателями акмеологических и психолингвистических ресурсов; исследовании различий

в показателях ресурсов и адаптации украинских эмигрантов, которые занимаются писательской и научной деятельностью по сравнению $с$ эмигрантами, которые ею не занимаются.

Материалы и методики исследования. Основными показателями акмереализации эмигрантов выделено смысложизненные ориентации, психологчческой позицию, социокультурную адаптацию. Диагностический инструментарий в соответствии включил тест смысложизненных ориентаций (Д. Леонтьева), что является адаптированной версией теста "Цель в жизни» (Purpose-in-LifeTest, PIL) Джеймса крамбе и Леонарда Махолика, методику Дж. Пауэлла "Полнота жизни», опросник адаптации личности к новой социокультурной среды (по Л. Янковским). Корреляционный анализ показал значимые умеренные корреляции между: (1) адаптивностью как типом адаптации и ориентацией на процесс жизни и внутренним локусом контроля;

(2) депрессивностью, ностальгией, отчужденностью как типами адаптации и шкалой "Какий другие» методики "Полнота жизни»; (3) конформностью, интерактивностью как типами адаптации и шкалой “Какой я» методики «Полнота жизни».

Результаты. Обнаружена прямая корреляционная связь между показателями такого типа адаптации, как "Адаптивность» и шкалы смысложизненных ориентаций - «Процесс жизни» и "Локус контроля Я»; прямая коррелячионная связь между показателями типа адаптации эмигрантов "Адаптивность» и обратная между типами "Депрессивность», "Ностальгия», "Отчуждение» с показателем шкалы "Какие другие»; прямая связь шкал адаптации "Конфрормность», "Интерактивность» со шкалой «Какой Я». Таким образом выяснено, что стремление к самореализации эмигрантов находится в зависимости от интереса и эмоциональной насыщенности жизни, представления о себе и позитивного восприятия других.

Статистически подтверждены результаты исследования свидетельствуют и о различиях в показателях ресурсов эмигрантов, которые занимаются писательской и научной деятельностью по сравнению с эмигрантами, которые не занимаются этой деятельностью. Выявлено значимые различия для шкалы "Адаптивность» и "Депрессивность» опросника адаптации; прослежены значимые различия для шкалы «Процесс жизни» опросника смысложизненных 
Психолінгвістичні ресурси реалізації акмепотенцііалу життєвих...

ориентаций; исследовано значимые различия и для шкалы «Какие другие» методики «Полнота жизни».

Отмечено, что украинские мигранты, которые генерируют тексты, имеют более гармоничный тип адаптации, чаще воспринимают процесс жизни как полон смысла, по сравнению с теми эмигрантами, чья деятельность не включает наративизации. Полученные результаты свидетельствуют о весомости разработки акме технологий для украинских эмигрантов через призму методологии психолингвистики.

Ключевые слова: психолингвистические ресурсы, жизненный сценарий, акме потенциал, наративизация, писатели-эмигранты. 